University of California, Hastings College of the Law UC Hastings Scholarship Repository

Faculty Scholarship

1993

\title{
The Effect of Economic Integration on Environmental Standards
}

Joel R. Paul

UC Hastings College of the Law, paulj@uchastings.edu

Follow this and additional works at: http://repository.uchastings.edu/faculty_scholarship

Part of the International Law Commons

\section{Recommended Citation}

Joel R. Paul, The Effect of Economic Integration on Environmental Standards, 87 Am. Soc'y Int'l L. Proc. 470 (1993).

Available at: http://repository.uchastings.edu/faculty_scholarship/632

This Article is brought to you for free and open access by UC Hastings Scholarship Repository. It has been accepted for inclusion in Faculty Scholarship

by an authorized administrator of UC Hastings Scholarship Repository. For more information, please contact marcusc@uchastings.edu. 


\section{Faculty Publications \\ UC Hastings College of the Law Library}

Author: Joel R. Paul

Source: $\quad$ American Society of International Law Proceedings

Citation: $\quad 87$ Am. Soc'y Int'I L. Proc. 470 (1993).

Title: $\quad$ The Effect of Economic Integration on Environmental Standards

Originally published in AMERICAN SOCIETY OF INTERNATIONAL LAW PROCEEDINGS. This article is reprinted with permission from AMERICAN SOCIETY OF INTERNATIONAL LAW PROCEEDINGS and American Society of International Law . 
nizing enactments respect the already existing framework of internationally applicable choice-of-law rules. ${ }^{42}$

Finally, we need to acknowledge that the concept of public policy is an evolving one, in private as well as in public international law (jus cogens). "Public policy" is traditionally resorted to "on the basis of central and fundamental legal principles, values or interests of the State involved, to ward off the results of application of foreign law." 43 Yet, in the public international law arena, the notion of supranational fundamental rights or principles is steadily gaining ground. ${ }^{44}$ This trend is also well established in the jurisprudence of the European Court of Justice. ${ }^{45}$ It is ironic that the doctrine of ordre public can simultaneously serve the goals of both universalism and particularism. Already within the EC, there is a growing recognition that the concept of ordre public is no longer limited to national but must also accommodate the "ordre public communautaire." 46 Indeed, many scholars expect that the European Court will "review the way in which national courts make use of the public policy exception" under the Brussels Convention, ${ }^{47}$ while others would deny this competence to the European Court. According to Jessurun d'Oliveira, "[p]ublic policy is an autonomous concept, which may be interpreted independently from the insights of national judges by the European Court." 48 These developments suggest that a similar evolution may gradually occur within the broader framework of other regional or global PIL efforts, although certainly not to the same extent as is likely to be achieved within the EC. We might start by fostering the development of supranational principles of contractual fairness to govern international commercial transactions.

\section{The EfFect of Economic Integration on Environmental StandardS}

$$
\text { By Joel R. Paul* }
$$

Today, we witness the steady growth of free trade areas and customs unions as one of the central characteristics of the new international economic order in Western Europe and the Americas. One of the principal concerns of regional economic integration has been its effect on domestic economic regulation-in particular, on environmental protection. The current debate over the ratification

\footnotetext{
${ }^{42}$ See H. Jessurun d'Oliveira, Towards a "European" Private International Law?, in B. DE WITTE \& Caroline Forder (eds.), The Common law of Europe and the Future of Legal Education 265, 266-67 (1991) (noting the "[g]rowing bulk of Community and para-Community conflict provisions" and that "the necessity to deal with rules from international sources" means that modern PIL codifications "have become interstitional, filling up the spaces which conventions have left open").

${ }^{43}$ See Jessurun d'Oliveira, supra note 42, at 276.

${ }^{44}$ See Gennady M. Danilenko, International Jus Cogens: Issues of Law-Making, 2 EUR. J. INT'L. L. 42 (1991).

${ }^{45}$ See Tebbens, supra note 21 , at 68 (arguing that the "principles of proportionality and of nondiscrimination" may "reduce the freedom of the Member States to invoke their public policy," citing as an example the German rule restricting recovery in tort against German nationals to the extent allowed by German law, even if foreign law governs the tort).

${ }^{46}$ Tebbens, supra note 21, at 69 (discussing Article 16 of the Rome Convention and inquiring into the extent to which "Member States may declare their own rules, e.g., consumer protection, to be mandatory for the purpose of applying the Rome Convention in areas such as supply of financial services where EC directives allow foreign service suppliers to deal on terms fixed by the law of their own State").

47 Jessurun d'Oliveira, supra note 42, at 276.

${ }^{48}$ Id. at 277 (citing examples from EC case law and legislation).

* Washington College of Law, The American University.
} 
of the North America Free Trade Agreement (NAFTA) turns largely on the need to reconcile the free trade area with the enforcement of domestic environmental policy. The concern is both that U.S. firms may move to Mexico to avoid burdensome regulations unless the United States lowers its own standards, and that increased environmental damage in Mexico resulting from increased industrial production for trade will spill across the U.S. border. However highly we value regional economic integration, we cannot ignore these environmental concerns.

The conventional argument that regional economic integration invites a downward spiral of falling regulatory standards and enforcement is familiar to all of us. We need a theory to help us understand and predict the consequences of economic integration on environmental standards. Economic integration involves a complex of public and private factors that deserves careful study, and I argue that we cannot presume a priori that economic integration leads to a diminution of environmental standards and enforcement.

To better understand the consequences of economic integration on environmental standards, it is worth considering the process of environmental harmonization now occurring in the European Community. Let me describe the character of EC environmental regulation and the impact of economic integration on environmental standards there.

\section{EC Environmental Legislation}

Although the Community has addressed environmental issues since the late 1960s, the Community's authority to legislate was clarified only in 1986 with the Single European Act (SEA) amendments to the Treaty of Rome. The SEA added two sections relevant to environmental legislation.

First, under Article 100A, the Treaty of Rome empowers the Council to adopt measures proposed by the Commission necessary for the establishment of the internal market by a qualified majority vote with the cooperation of the European Parliament. Under Article 100A, the Council has adopted measures to establish common environmental standards and avoid distortions to the free movement of goods that might result if member states pursue conflicting policies. In proposing measures under Article $100 \mathrm{~A}$, the Commission is required to assume a "high level of protection," and under Article 100A(4), member states may under certain circumstances apply more stringent national measures to protect the environment. For example, the European Court of Justice has held that municipalities may adopt regulations banning plastic trash bags, even though the Council's directives on solid waste disposal do not provide for such laws. ${ }^{1}$

The SEA also added Articles 130R-T, setting out fundamental priorities and means to guide EC environmental policy. These priorities include prevention of pollution before it occurs, rectification of the damage at its source (requiring the polluter to bear the cost of cleanup), and subsidiarity-that is, the principle that the Community should act only when the member state or local authority cannot act effectively. Under Article $130 \mathrm{~S}$, the Council is empowered to implement these priorities by unanimous action based on a Commission proposal without Parliament's consent.

\section{The Question of Legal Basis}

Thus, the Council has two procedures for enacting environmental standards. Under Article $130 \mathrm{~S}$, the Council must act unanimously but does not require Parlia-

\footnotetext{
${ }^{1}$ Case 380/87, Enichem Base S.p.A. v. Municipality of Cinisello Balsamo, 1989 O.J. (C207) (holding that the 1975 Directive on Waste does not prevent a commune from banning nonbiodegradable plastic trash bags).
} 
ment's approval. Under Article $100 \mathrm{~A}$, the Council can act with a mere qualified majority, so long as a majority of Parliament concurs. In effect, Article 100A has strengthened the relatively "green" voice within the Parliament, while 130S has been employed to adopt more moderate measures that command support from all member states within the Council.

A subject of some controversy is which of these two procedures is the appropriate legal basis for environmental legislation. If there is no nexus to the free movement of goods or services, it is relatively clear that the only appropriate legal basis is $130 \mathrm{~S}$. For example, there is no doubt now that the appropriate legal basis for legislation protecting wildlife is Article 130S. However, the legal basis for measures concerning the regulation of industry is often open to dispute. Repeatedly, the Commission has proposed legislation affecting industrial pollution based on Article $100 \mathrm{~A}$, and the Council has adopted such measures on the basis of Article 130S. In this way, the Council has cut Parliament out of the legislative process. The Commission has contested the Council's action, but it has not been clear how far the Commission can go in relying on Article $100 \mathrm{~A}$ as a legal basis for protecting the environment.

The European Court of Justice has addressed this question in two recent judgments, with conflicting conclusions. First, in the Titanium Dioxide case, ${ }^{2}$ the Commission challenged the Council's adoption of a directive prohibiting the dumping of titanium dioxide waste into water. The Council decided that the directive was aimed at environmental regulation and approved it unanimously under Article 130S. The Court, however, struck down the Council's action and sided with the Commission's view that the titanium dioxide regulation should be based on Article $100 \mathrm{~A}$. The Court set out in its judgment the principle that if a measure contains both environmental and internal market-related objectives, the appropriate legal basis is Article 100A. In effect, the Court has expressed a strong preference for Article 100A cooperation procedures. The Titanium Dioxide case represented a victory for the Parliament and the Commission over the Council. After Titanium Dioxide, we might have reasonably anticipated that the Commission and the Parliament would use this decision to raise environmental standards. In March 1993, the Court revisited the question in a case brought by the Commission against the Council, challenging the legal basis for Directive $91 / 156$ on waste regulation. The Commission sought to annul the Directive, which was promulgated under Article 130 S, by arguing that the Titanium Dioxide judgment required that the Directive on waste be enacted under $100 \mathrm{~A}$.

In its judgment, ${ }^{3}$ the Court rejected the Commission's argument for $100 \mathrm{~A}$ as the appropriate legal basis. The Court found that the effect of Directive 91/156 on harmonization was merely ancillary to the primary purpose, namely, to protect the environment. Accordingly, the Court concluded that the appropriate legal basis was $130 \mathrm{~S}$.

It is difficult to reconcile the Court's judgments in the Titanium Dioxide and the Waste Directive cases. It appears that since the Waste Directive judgment, the Court has returned to some form of center-of-gravity analysis, weighing the relative significance of environmental and harmonization consequences of particular measures. In doing so, the Court has left unresolved whether the Council or the Parliament will enjoy an advantage in legislating environmental protection.

It should be noted that, under $130 \mathrm{~S}$, member states may introduce more stringent

${ }^{2}$ Case C-300/89, Commission v. Council, 1991.

${ }^{3}$ Case C-155/91, Commission v. Council, 1993. 
environmental protective measures compatible with the Treaty. The power of individual member states to act thus is not compromised by requiring $130 \mathrm{~S}$ as the appropriate legal basis.

\section{The Fifth Environmental Action Program}

Since member states have the right to adopt more stringent environmental standards, we must consider how member states in actual practice have been affected by the Community in legislating and enforcing environmental standards. We might, for example, posit that member states' legislatures would be reluctant to adopt higher standards, either on the assumption that they would be struck down by the Court as interfering with the free movement of goods protected by Articles 30 , et seq., or that member states would fear the flight of industry that could follow if they established standards that unduly burdened their own producers.

In fact, there is some evidence that the internal market has created pressure at both community and national levels toward raising at least some environmental standards and accelerating the pace of legislation. In December, 1992, the Council adopted the Community's Fifth Action Program for the Environment and Sustainable Development. This program sets forth a bold new strategy that redefines economic development as growth that is not detrimental to the environment on which economic and social development relies. One of the most ambitious aspects of the program concerns waste management. To this end, the Commission has proposed a directive on packaging to minimize waste. The proposed directive is an interesting case study in the interaction of national and EC legislation involving both public and private actors.

\section{The Directive on Packaging}

The most striking example of the interaction of national and EC regulation raising environmental standards is in the area of recycling packaging wastes. The EC produces 50 million tons of packaging waste each year, but recycles less than 20 percent of that amount. As existing landfill sites are exhausted, member states have considered and adopted a range of measures designed to facilitate recycling and eliminate waste.

In June, 1991, the Netherlands negotiated a voluntary covenant with industry providing that industry will reduce the weight of packaging by 10 percent and will participate in reusing, recycling or recovering energy from all packaging waste by the end of this decade. The covenant provides that by the year 2000 no packaging waste will be dumped in landfills, and that excessive packaging and nonrefillable containers will be eliminated. It is a legally enforceable contract between industry and government.

Also in June, 1991, Germany enacted a law holding all distributors responsible for the reuse and recycling of packaging. Distributors are required to either remove all packaging before sale or provide for the collection of packaging waste. They are exempt from this requirement, however, for the sale of any product displaying a "green dot." The green dot indicates that the product's manufacturer is licensed to collect and recycle waste packaging through a private nonprofit enterprise called the "Dual System Deutschland" (DSD), which is financed by a charge to manufacturers for the use of the green dot. The fee costs manufacturers about one to three pfennings per item, depending on the weight of the product. The DSD collects and sorts packaging directly from private households and delivers waste material (without charge) to private enterprises for recycling or recovery of materials or energy. The DSD began operations in July 1991 with the participation of more than 600 companies. By 1995, about 80 percent of all German packaging will 
be recovered through DSD. German consumers have responded to the recycling program with such enthusiasm that DSD has been overwhelmed by more waste than it has the capacity to recycle within Germany. As a result, DSD has been required to pay recyclers to take waste off its hands and has had to export waste for recycling or landfills elsewhere. At one point earlier this year, DSD's financial solvency was threatened, but that has now been resolved by charging manufacturers higher fees to use the green dot.

The DSD has provided German recyclers with an abundant source of free basic materials. As a result, paper millers and plastic manufacturers elsewhere in Europe are complaining that the scheme provides German industry with an unfair advantage; about half of all paper products in Germany are now manufactured from waste paper provided free by the DSD.

The European Plastic Association has called on the Community to adopt a Community-wide program of mandatory recycling to create a level playing field for plastic manufacturers outside Germany. The DSD has become so successful in cutting the cost of recycling that it threatens to control the recycling industry. In fact, the German Cartel Office is investigating DSD for possible violation of the monopoly laws.

Last month, the Government of France announced that it, too, would establish a "green-dot" program through a consortium of government and industry known as "Eco-Emballage," and French plastic manufacturers independently have established a consortium, called "Valorplast," to facilitate plastic recycling so as to better compete with the German plastics manufacturers.

These national efforts to minimize and recycle packaging waste threaten to disrupt the free movement of goods across national boundaries. How, for example, can a French company sell mineral water in Germany if it is required to recycle its own packaging? Is it fair to expect all European companies to join the DSD in Germany? Will they be required to adopt different packages for each of the twelve member state markets? These concerns prompted the Commission to propose a directive harmonizing national laws on packaging waste that is now being considered by the European Parliament.

The proposal on packaging and packaging waste ${ }^{4}$ aims to harmonize national measures under Article 100A. The proposed directive establishes as targets the recovery of 90 percent of packaging waste, by weight, within ten years. Recovery includes reuse of packaging, recycling of waste materials and recovery of energy through incineration. Within this general recovery target, 60 percent of packaging waste output would be recycled. Within five years the directive requires member states to ensure that systems are set up to provide for the return and recovery of all used packaging, including all imported products under nondiscriminatory conditions. Such systems should provide for participation by industry. To facilitate recovery, the directive provides for a system of marking on all packaging indicating whether it is reusable or recoverable. In addition, the directive provides for the creation of data bases to enable the Commission to adopt packaging waste management policies and for public education to ensure that consumers are aware of the advantages of using reusable and recoverable packages.

The proposed directive leaves to member states the choice of instrument for the attainment of the recovery targets. Presumably, manufacturers and/or distributors would participate through either voluntary or mandatory schemes to collect, sort,

${ }^{4}$ Case C-263/01, 1992 O.J. (C263) 1. 
recycle or reuse packaging waste. Consistent with the principle that the polluter should pay for the cost of cleanup, it is expected that the directive would shift the burden of waste onto its source, to give the private sector an economic incentive for minimizing waste and developing new markets for recoverable materials.

The directive has also been criticized in the Parliament and by environmental and consumer groups as insufficient in a number of respects. Denmark and some environmental groups have objected that the directive does not ban hazardous substances in packaging, such as polyvinyl chlorides. The Benelux countries and France have complained that the directive gives member states too much discretion in setting specific targets for recycling, reusing and energy generation. The Benelux and Germany want the directive to require producers to be responsible for collecting and recovering waste either by charging a deposit or arranging for collection at the point of sale, or by establishing a consortium of European producers to collect and recover waste. The Commission has responded that the appropriateness of requiring refillable containers or recycling or heat generation depends upon the availability of water and alternative energy sources and the cost of transporting refillable containers back to the place of manufacture. For example, France intends to incinerate about 75 percent of all packaging waste for energy, while the Netherlands, Denmark, Belgium and Spain prefer to reuse containers. France and Spain have also called for requiring the redesign of packages to minimize unnecessary packaging. Germany opposes such standards, however, insisting that manufacturers will have an economic incentive to minimize packaging if appropriate national legislation is adopted that uses economic measures to shift the burden of recovery to private enterprise. Finally, Greece and Ireland have argued that the directive does nothing to relieve the financial hardship on states with deficient infrastructure to facilitate the collection and recovery of packaging waste.

Despite these criticisms, the directive enjoys broad support from all member states and, perhaps surprisingly, from industry. Most manufacturers believe that such Community-wide legislation is the only way to avoid segregating national markets. Some trade associations have argued that by providing an incentive to reduce packaging across the board, the EC directive will cut packaging costs. Other trade associations, such as paper millers, stand to benefit from an oversupply of recyclable material and an educated, "green" consuming public.

The packaging directive is encouraging evidence that the process of economic integration need not lead to a downward spiral of environmental standards. Rather, it illustrates a dialectical relationship between national regulatory and Community authorities, in which the Community acts to harmonize standards to avoid the member states going their separate ways.

\section{Toward a General Theory}

How do we explain the apparent anomaly that waste management standards have been improved, rather than lowered, by the Community's economic integration? First, an obvious factor is that, unlike other forms of environmental regulation, the packaging directive is effective at the point of consumption rather than production. Thus, regardless of where the goods originate, all goods consumed within the territory are subject to a common standard. There is no opportunity for manufacturers to avoid the regulatory jurisdiction; so long as manufacturers want to sell in the German market, they will have to participate in its waste man-

agement program. Moreover, imposing conditions on market access in this way encourages other states to raise their standards to avoid distortions in the pattern 
of trade. For companies in the Benelux countries to remain competitive in the German market, they should adopt equivalent standards, so that they have an opportunity to reach the economies of scale that justify redesigning their packages for the German market.

If we were to attempt a general theory of how environmental regulations are affected by trade, we might start with this proposition: It depends on whether the regulations are effective at the point of consumption or of production.

A second factor to consider is whether there is some institutional authority with a long-term view for negotiating legislation and enforcing new standards, such as the Commission and the Council. One of the weaknesses in NAFTA in this regard is the absence of an institutional framework competent to enforce standards. The Clinton Administration has sought to address this problem in its negotiations over the appropriate enforcement role of the North American Commission for the Environment (NACE). Thirdly, the competitive structure of the regulated industry is critical in determining whether regulations can be raised consistent with economic integration. In a highly competitive market, where profit margins are low, firms with small profit margins may not survive the added cost of regulation. Indeed, we could postulate that as a practical matter it is far easier for regulators to enforce regulation against a monopoly or an oligopoly than against an industry composed of hundreds of relatively small firms. ${ }^{5}$ Moreover, in a market with many marginally profitable small firms, it may not be politically feasible to impose higher regulatory standards. If a concentrated industry can withstand environmental regulation that a more competitive industry may not, competition policy and environmental policy may in some cases be fundamentally in conflict. And the conflict between competition policy and environmental policy may be particularly acute as market integration develops. Unless domestic firms have some protection from foreign producers not subject to the same level of environmental regulation, they may not be able to absorb costs or pass them along to consumers.

Finally, a theory of how trade affects regulation must consider the way private international law allows parties to opt out of the domestic scheme of regulation. For example, to the extent that courts allow private companies to choose foreign law to govern aspects of their transactions or to settle disputes in foreign courts or before private arbitrators, such companies may be able to insulate themselves from certain forms of regulation. ${ }^{6}$

\section{Conclusion}

In sum, the conflict now presumed to exist between economic integration and environmental protection may be more imagined than real. In fact, economic integration may actually raise environmental standards. Further study is required to formulate a theory of harmonization; as a preliminary step, I have suggested four factors that may determine whether economic integration has a positive or negative effect on environmental standards:

\footnotetext{
${ }^{5}$ For example, the lumber milling industry in the northwest United States is primarily composed of small, family-owned mills scattered throughout northern California, Oregon, Washington and Idaho. These mills are notoriously under-regulated, in terms of both air quality controls and occupational safety standards. By comparison, the U.S. automobile industry, which is highly concentrated, is therefore closely regulated, and enforcement is generally quite effective.

${ }^{6}$ A good example of this is the Supreme Court's decision in The Bremen v. Zapata to enforce the parties' foreign choice of forum clause, even where the foreign forum would apply an otherwise illegal exculpatory clause that excused a towboat operator from liability for its own negligence at sea. Had the Court insisted that a U.S. court hear the case, it would have foreclosed one avenue for escaping U.S. jurisdiction, and by doing so, it would have provided a higher level of protection against environmental damage at sea.
} 